\title{
ODC1 wt Allele
}

National Cancer Institute

\section{Source}

National Cancer Institute. ODC1 wt Allele. NCI Thesaurus. Code C50398.

Human ODC1 wild-type allele is located within 2p25 and is approximately $8 \mathrm{~kb}$ in length.

This allele, which encodes ornithine decarboxylase protein, is involved in the conversion of ornithine to putrescine in the first step of the polyamine biosynthesis pathway. The ODC gene is associated with several types of human cancer such as esophageal cancer, meningiomas and prostate cancer. 